\title{
Penerapan Quality Of Service (QoS) dengan Metode PCQ untuk Manajemen Bandwidth Internet pada WLAN Politeknik Negeri Madiun
}

\author{
Hendrik Kusbandono*1, Eva Mirza Syafitri ${ }^{2}$ \\ ${ }^{1}$ Program Studi Teknologi Informasi, ${ }^{1}$ Program Studi Administrasi Bisnis \\ Politeknik Negeri Madiun \\ e-mail: *113ndrik57@pnm.ac.id, ${ }^{2}$ evamirzas@pnm.ac.id
}

\begin{abstract}
Teknologi Wireless LAN difungsikan untuk memfasilitasi kemudahan untuk koneksi jaringan, tidak lain termasuk jaringan internet. Manajemen bandwidth merupakan mengalokasikan suatu bandwidth yang berfungsi untuk mendukung kebutuhan atau keperluan suatu jaringan internet agar memberikan jaminan kualitas layanan suatu jaringan QoS (Quality of Services). Dengan tujuan untuk mengetahui bagaimana kualitas layanan dan kinerja jaringan Wireless LAN (WLAN), serta mengoptimalkan pembagian bandwidth secara merata ke sejumlah client yang aktif. Metode penelitian ini adalah penerapan Quality of Service (QoS) yang digunakan untuk mengukur kualitas bandwidth internet yang berjalan pada Wireless LAN dengan parameter download, upload, throughput, delay, jitter, dan packet loss dan manajemen bandwidth dengan PCQ (Per Connection Queue). Hasil penelitian ini adalah pada rentang waktu $08.00 \mathrm{~s} / \mathrm{d} 16.00$ WIB quota IP Address dinamis habis, sehingga tidak dapat mengkoneksikan ke hotspot PNM-MHS. Menunjukkan rata-rata nilai sebelum dilakukan manajemen bandwidth metode PCQ pada throughput adalah 374,98 Kbps, nilai delay adalah 40,16 ms dengan kategori latensi "Sangat Bagus", nilai jitter adalah 99,43 ms dengan kategori degradasi "Sedang", nilai packet loss adalah 23,94 \% dengan kategori degredasi "Sedang". Sedangkan setelah melakukan manajemen bandwidth nilai throughput adalah 362,56 Kbps, nilai delay adalah 29,84 ms dengan kategori latensi "Sangat Bagus", nilai jitter adalah 55,53 ms dengan kategori degradasi "Bagus", nilai packet loss adalah 14,29 \% dengan kategori degredasi "Bagus". Manajemen bandwidth metode PCQ bekerja dengan sebuah algoritma yang akan membagi bandwidth secara merata ke sejumlah client yang aktif. PCQ ideal diterapkan apabila dalam pengaturan bandwidth kesulitan dalam penentuan bandwidth per client.
\end{abstract}

\section{Kata kunci : Wireless LAN (WLAN), Quality of Services, Bandwidth, PCQ (Per Connection Queue)}

\section{PENDAHULUAN}

Seiring dengan berkembangnya teknologi informasi dan komunikasi, menuntut perubahan yang besar di dalam sistem pendidikan nasional, termasuk perguruan tinggi. Implementasi teknologi informasi tidak hanya berguna untuk hal-hal yang memang secara langsung mengeksploitasi potensi teknologi, tapi juga mendorong munculnya ide-ide baru dalam melakukan aktivitas/kegiatan.

Politeknik Negeri Madiun (PNM) merupakan Perguruan Tinggi Negeri di Madiun yang melakukan berbagai inovasi dalam mengimplemntasikan teknologi informasi untuk mendukung dan menyelerasakan visi misi perguruan tinggi. Hal ini didukung oleh UPT Teknologi Informasi dengan visi-nya sebagai pusat pengelolaan, pelayanan, dan pengembangan teknologi informasi yang mendukung kegiatan Tridharma Perguruan Tinggi dan tata kelola organisasi. Dengan kapasitas kelola 6 program studi, yaitu Administrasi Bisnis, Komputerisasi Akuntansi, Teknik Komputer Kontrol, Teknik Listrik, Mesin Otomotif, dan Bahasa Inggris.

Implemantasi teknologi Wireless LAN (WLAN) (atau umunya disebut dengan hotspot) di tiap-tiap titik kampus Politeknik Negeri Madiun, khususnya gedung M. NUH difungsikan untuk memfasilitasi koneksi internet, baik untuk Dosen, Karyawan, maupun Mahasiswa. Gedung M. NUH terdapat tiga lantai, dengan tiap-tiap lantai terdapat beberapa titik terpasang perangkat Wireless LAN. Dari perangkat hotspot di berbagai sudut titik diharapkan dapat memberikan layanan koneksi internet dengan baik, yang difungsikan untuk kebutuhan proses perkuliahan maupun akademik.

Fasilitas di lantai 1 (satu), 2 (dua), maupun 3 (tiga) tidak hanya dalam kelas saja, di luar kelas pun harus berfungsi dengan baik. Kenyataannya tidak demikian, laptop/notebook sering terjadi sulitnya terkoneksi dengan perangkat Wireless LAN (hotspot), apabila dapat terkoneksi dengan jaringan, akan tetapi koneksi akses internet kurang baik. Hal-hal seperti ini sering dijumpai oleh dosen maupun mahasiswa di dalam kelas atau luar kelas, apalagi pada waktu-waktu padat dengan mahasiswa (pukul $08.00 \mathrm{~s} / \mathrm{d} 16.00 \mathrm{WIB}$ ).

Jaringan yang terkoneksi internet, baik yang menggunakan media kabel ataupun wireless LAN (WLAN), akan dipengaruhi masalah besarnya kapasitas bandwidth dan seberapa efektif bandwidth dapat digunakan untuk kerlancar transmisi data upload maupun download. Bandwidth merupakan kapasitas 
atau daya tampung kabel ethernet agar dapat dilewati trafik paket data dalam jumlah tertentu [1].

Penggunaan bandwidth pada umumnya seringkali tidak difungsikan dengan optimal. Hal ini dapat disebabkan oleh adanya satu atau lebih client yang menghabiskan kapasitas bandwidth untuk proses download maupun mengakses aplikasi-aplikasi yang dapat menyita kapasitas bandwidth. Semakin baik kualitas bandwidth yang diberikan, maka pengguna juga semakin nyaman dalam menggunakan jaringan. Penerapan jaringan berbasis wireless harus memiliki sebuah standar layanan atau yang dikenal sebagai Quality of Services (QoS). QoS merupakan kemampuan sebuah jaringan untuk menyediakan layanan trafik data yang melewatinya. Pada operting system mikrotik, metode PCQ (Per Connection Queue) merupakan program untuk mengelola jaringan lalu lintas pada Quality of Service (QoS) [2]. Metode manajemen bandwidth dengan PCQ (Per Connection Queue) berfungsi untuk melakukan bandwidth sharing otomatis dan merata ke multi client.

\section{LANDASAN TEORI}

\section{a. Quality of Service (QoS)}

Quality of Service (QoS) merupakan metode pengukuran tentang seberapa baik jaringan dan merupakan suatu usaha untuk mendefinisikan karakteristik dan sifat dari satu layanan. QoS berfungsi untuk mengukur sekumpulan atribut kinerja yang telah dispesifikasikan dan diasosiasikan dengan suatu layanan [3].

Tabel 1. Persentase dan nilai Quality of Service (QoS)

\begin{tabular}{|c|c|c|}
\hline Nilai & Persentase (\%) & Indeks \\
\hline $3,8-4$ & $95-100$ & Sangat Memuaskan \\
\hline $3-3,79$ & $75-94,75$ & Memuaskan \\
\hline $2-2,99$ & $50-74,75$ & Kurang Memuaskan \\
\hline $1-1,99$ & $25-49,75$ & Jelek \\
\hline
\end{tabular}

(TIPHON, 1999)

Tujuan QoS adalah untuk memenuhi kebutuhankebutuhan layanan yang berbeda dengan menggunakan infrastruktur yang sama. Elemen kinerja jaringan dalam cakupan QoS seringkali termasuk ketersediaan (uptime), bandwith (throughput), keterlambatan (latency/delay), dan tingkat kesalahan. Beberapa parameter yang dapat digunakan untuk penilaian Quality of Service (QoS) yaitu Throughput, Delay (Latency), Jitter (Variasi kedatangan paket), dan Packet Loss [4].

\section{1) Throughput}

Throughput merupakan kecepatan (rate) transfer data efektif, yang diukur dalam bps (bit per second). Throughput adalah jumlah total kedatangan paket yang sukses yang diamati pada tujuan selama interval waktu tertentu dibagi oleh durasi interval waktu.

Tabel 2. Parameter Throughput

\begin{tabular}{|c|c|c|}
\hline Kategori & Throughput & Indeks \\
\hline Sangat Bagus & $100 \%$ & 4 \\
\hline Bagus & $75 \%$ & 3 \\
\hline Sedang & $50 \%$ & 2 \\
\hline Jelek & $<25 \%$ & 1 \\
\hline
\end{tabular}

(TIPHON, 1999)

Persamaan perhitungan throughput :

Throughput $=\frac{\text { Paket data diterima }}{\text { Lama pengamatan }}$

2) Delay (Latency)

Merupakan total waktu yang dilalui suatu paket dari pengirim ke penerima melalui jaringan. Delay dapat dipengaruhi oleh jarak, media fisik, kongesti atau juga waktu proses yang lama.

Tabel 3. Parameter Delay (Latency)

\begin{tabular}{|c|c|c|}
\hline Kategori & Delay & Indeks \\
\hline Sangat Bagus & $<150 \mathrm{~ms}$ & 4 \\
\hline Bagus & $150 \mathrm{~s} / \mathrm{d} 300 \mathrm{~ms}$ & 3 \\
\hline Sedang & $300 \mathrm{~s} / \mathrm{d} 450 \mathrm{~ms}$ & 2 \\
\hline Jelek & $>450 \mathrm{~ms}$ & 1 \\
\hline
\end{tabular}

(TIPHON, 1999)

Persamaan perhitungan delay (latency) :

Delay rata - rata $\frac{\text { Total delay }}{\text { Total paket yang diterima }}$

3) Jitter (Variasi kedatangan paket)

Merupakan variasi dari delay end-to-end. Levellevel yang tinggi pada jitter dalam aplikasi-aplikasi berbasis UDP merupakan situasi yang tidak dapat diterima dimana aplikasi-aplikasinya merupakan aplikasi-aplikasi real-time. Pada kasus seperti itu, jitter akan menyebabkan sinyal terdistorsi, yang dapat diperbaiki hanya dengan meningkatkan buffer di antrian.

Tabel 4. Parameter Jitter

\begin{tabular}{|c|c|c|}
\hline Kategori & Jitter & Indeks \\
\hline Sangat Bagus & $0 \mathrm{~ms}$ & 4 \\
\hline Bagus & $0 \mathrm{~s} / \mathrm{d} 75 \mathrm{~ms}$ & 3 \\
\hline Sedang & $75 \mathrm{~s} / \mathrm{d} 125 \mathrm{~ms}$ & 2 \\
\hline Jelek & $125 \mathrm{~s} / \mathrm{d} 225 \mathrm{~ms}$ & 1 \\
\hline
\end{tabular}

(TIPHON, 1999)

Persamaan perhitungan jitter :

fitter $=\frac{\text { Total variansi delay }}{\text { Totalpaketyang diterima }}$

4) Packet Loss 
Merupakan suatu parameter yang menggambarkan suatu kondisi yang menunjukkan jumlah total paket yang hilang, dapat terjadi karena collision dan congestion pada jaringan. Umumnya perangkat jaringan memiliki buffer untuk menampung data yang diterima. Jika terjadi kongesti yang cukup lama, buffer akan penuh, dan data baru tidak akan diterima.

Tabel 5. Parameter Packet Loss

\begin{tabular}{|c|c|c|}
\hline Kategori & Packet Loss & Indeks \\
\hline Sangat Bagus & $0 \%$ & 4 \\
\hline Bagus & $3 \%$ & 3 \\
\hline Sedang & $15 \%$ & 2 \\
\hline Jelek & $25 \%$ & 1 \\
\hline
\end{tabular}

TIPHON, 1999)

Persamaan perhitungan Packet Loss :

Paket Loss $=\left(\frac{\text { Datayang dikirim }- \text { paket data yang diterima }}{\text { Paket data yang dikirim }}\right) \times 100 \%$

\section{b. Manajemen Bandwidth}

Bandwidth Management adalah suatu cara yang dapat digunakan untuk management dan mengoptimalkan berbagai jenis jaringan dengan menerapkan layanan Quality Of Service (QoS) untuk menetapkan tipe-tipe lalu lintas jaringan. Sedangkan QoS adalah kemampuan untuk menggambarkan suatu tingkatan pencapaian didalam suatu sistem komunikasi data [5].

\section{c. Metode PCQ (Per Connection Queue)}

PCQ (Per Connection Queue) pada queue type merupakan salah satu feature dari MikroTik untuk membantu memanage traffic rate dan traffic packet. Pada operting system mikrotik, PCQ merupakan program untuk mengelola jaringan lalu lintas Quality of Service (QoS) [2]. Tujuan utama dari metode ini adalah untuk melakukan bandwidth sharing otomatis dan merata ke multi client[6]. Prinsip kerja metode PCQ adalah menerapkan simple queue dimana hanya ada satu client aktif yang menggunakan bandwidth, sementara client lain berada dalam posisi idle, maka client aktif tersebut dapat menggunakan bandwidth maksimum, tetapi jika client lain aktif, maka bandwidth yang maksimal dapat digunakan oleh kedua client, sehingga bandwidth dapat terdistribusi secara adil untuk semua client [7]. Cara kerja PCQ adalah dengan menambahkan sub-queue, berdasar classifier tertentu. Berikut Gambaran 2.1. cara kerja PCQ dengan parameter PCQ-Rate $=0$.

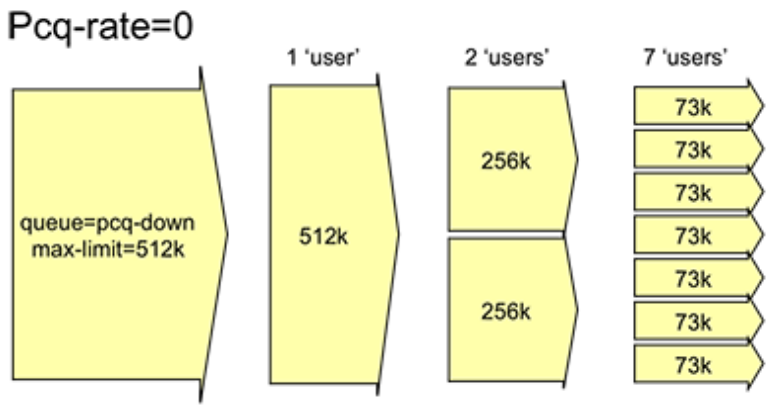

Gambar 1. Cara kerja PCQ

\section{d. Wireless Local Area Network (WLAN)}

Wireless Local Area Network (WLAN) merupakan jaringan komputer yang menggunakan frekuensi radio dan infrared sebagai media transmisi data. Wireless LAN sering disebut jaringan nirkabel atau jaringan wireless. Wireless LAN (WLAN) merupakan komunikasi wireless dalam lingkup area yang terbatas, biasanya antara 10 sampai dengan 100 meter dari base station ke Access Point (AP). keluarga IEEE 802.11 (seperti 802.11b, 802.11a, 802.11g), HomeRF, 802.15 (Personal Area Network) yang berbasis Bluetooth, 802.16 (Wireless Metropolitan Area Network) [8][9].

\section{METODE}

Metode penelitian ini menggunakan metode eksperimental dan studi pustaka yang melibatkan penyelidikan tentang proses pada setiap parameter dan variabel. Adapun metode penelitian yang digunakan di pada penelitian ini, diantaranya adalah :

\section{a. Pengumpulan Data}

Pengumpulan data dilakukan dengan cara studi pustaka, metode observasi, dan metode wawancara.

\section{b. Penerapan Quality of Service (QoS) dan PCQ} (Per Connection Queue)

- Pengujian QoS Sebelum

Tahapan ini adalah melakukan penerapan Quality of Service (QoS) untuk mengukur kualitas layanan dan kinerja jaringan Wireless LAN (WLAN) dengan parameter download, upload, throughput, delay, jitter, dan packet loss. Pengukuran terhadap parameter QoS dilakukan pada sesi jam sibuk (sekitar pukul 08.00-16.00 WIB). Sedangkan pengukuran parameter QoS, penulis menggunakan aplikasi Wireshark[10].

- Konfigurasi sistem dengan metode PCQ (Per Connection Queue) 
Tahapan ini adalah melakukan setting manajemen bandwidth internet dengan metode PCQ (Per Connection Queue) menggunakan router Mikrotik[11].

\section{- Pengujian QoS Sesudah}

Tahapan ini adalah melakukan penerapan Quality of Service (QoS) untuk mengukur kualitas layanan dan kinerja jaringan Wireless LAN (WLAN) setelah implementasi metode PCQ (Per Connection Queue).

\section{c. Analisis Quality of Service (QoS) dan PCQ (Per Connection Queue)}

Pada tahapan ini adalah analisis gap hasil pengukuran Quality of Service (QoS) baik sebelum maupun sesudah melakukan manajemen bandwidth internet dengan metode PCQ (Per Connection Queue) terhadap kualitas layanan dan kinerja jaringan Wireless LAN (WLAN).

\section{d. Alat dan Bahan Penelitian}

Adapun alat dan bahan pada penelitian ini, sebagai berikut :

1. Perangkat Keras (Hardware) yang digunakan, meliputi :

- Komputer (Laptop/Notebook) yang digunakan untuk mengukur kualitas layanan dan kinerja jaringan Wireless LAN (WLAN).

- Router Mikrotik digunakan untuk manajemen bandwidth internet dengan menggunakan metode PCQ (Per Connection Queue).

2. Perangkat Lunak (Software)

Perangkat software yang digunakan adalah Wireshark merupakan aplikasi yang digunakan untuk mengukur kualitas layanan dan kinerja jaringan Wireless LAN (WLAN). Wireshark merupakan sebuah software sniffer freeware yang dapat di download di www.wireshark.org.

\section{HASIL}

Adapun hasil rekap pengujian QoS sebelum melakukan manajemen bandwidth menggunakan metode PCQ (Per Connection Queue) pada Tabel 6, sedangkan sesudah melakukan manajemen bandwidth pada tabel 7 .

Tabel 6. Nilai pengujian QoS sebelum manajamen bandwidth

\begin{tabular}{|c|c|c|c|c|}
\hline Waktu Pengujian & Nilai Throughput & Nilai Delay & Nilai Jitter & Nilai Packet Los \\
\hline $08.00-10.00 \mathrm{WIB}$ & $256,52 \mathrm{Kbps}$ & $17,15 \mathrm{~ms}$ & $22,74 \mathrm{~ms}$ & $16,58 \%$ \\
\hline $11.00-12.00 \mathrm{WIB}$ & $104,58 \mathrm{Kbps}$ & $25,66 \mathrm{~ms}$ & $42,81 \mathrm{~ms}$ & $34,08 \%$ \\
\hline $12.00-14.00 \mathrm{WIB}$ & $10,56 \mathrm{Kbps}$ & $144,55 \mathrm{~ms}$ & $415,51 \mathrm{~ms}$ & $51,21 \%$ \\
\hline $14.00-15.00 \mathrm{WIB}$ & $447,22 \mathrm{Kbps}$ & $11,18 \mathrm{~ms}$ & $13,88 \mathrm{~ms}$ & $13,49 \%$ \\
\hline $15.00-16.00 \mathrm{WIB}$ & $1.056,03 \mathrm{Kbps}$ & $2,27 \mathrm{~ms}$ & $2,23 \mathrm{~ms}$ & $4,36 \%$ \\
\hline Rata-rata & $\mathbf{3 7 4 , 9 8}$ Kbps & $\mathbf{4 0 , 1 6} \mathbf{m s}$ & $\mathbf{9 9 , 4 3} \mathbf{~ m s}$ & $\mathbf{2 3 , 9 4} \%$ \\
\hline \multicolumn{2}{|c|}{ Kategori } & $\begin{array}{c}\text { Sangat } \\
\text { Bagus }\end{array}$ & Sedang & Sedang \\
\hline
\end{tabular}

Berdasarkan tabel diatas hasil perhitungan nilai parameter QoS sebelum melakukan manajamen bandwidth dengan rentang waktu, menunjukkan ratarata nilai throughput adalah $374,98 \mathrm{Kbps}$, sedangkan nilai delay adalah 40,16 ms dengan kategori latensi "Sangat Bagus", sedangkan nilai jitter adalah 99,43 ms dengan kategori degradasi "Sedang", sedangkan nilai packet loss adalah 23,94\% dengan kategori degredasi "Sedang".

Tabel 7 Nilai Pengujian Parameter QoS sesudah manajamen bandwidth

\begin{tabular}{|c|c|c|c|c|}
\hline Waktu Pengujian & Nilai Throughput & Nilai Delay & Nilai Jitter & Nilai Packet Los \\
\hline $08.00-10.00 \mathrm{WIB}$ & $240,12 \mathrm{Kbps}$ & $14,10 \mathrm{~ms}$ & $19,64 \mathrm{~ms}$ & $12,50 \%$ \\
\hline $11.00-12.00 \mathrm{WIB}$ & $110,52 \mathrm{Kbps}$ & $22,15 \mathrm{~ms}$ & $40,11 \mathrm{~ms}$ & $13,18 \%$ \\
\hline $12.00-14.00 \mathrm{WIB}$ & $90,86 \mathrm{Kbps}$ & $100,36 \mathrm{~ms}$ & $197,50 \mathrm{~ms}$ & $32,20 \%$ \\
\hline $14.00-15.00 \mathrm{WIB}$ & $401,26 \mathrm{Kbps}$ & $10,17 \mathrm{~ms}$ & $15,18 \mathrm{~ms}$ & $10,40 \%$ \\
\hline $15.00-16.00 \mathrm{WIB}$ & $970,03 \mathrm{Kbps}$ & $2,40 \mathrm{~ms}$ & $5,20 \mathrm{~ms}$ & $3,16 \%$ \\
\hline Rata-rata & $\mathbf{3 6 2 , 5 6} \mathbf{K b p s}$ & $\mathbf{2 9 , 8 4} \mathbf{~ m s}$ & $\mathbf{5 5 , 5 3} \mathbf{~ m s}$ & $\mathbf{1 4 , 2 9} \%$ \\
\hline \multicolumn{2}{|c|}{ Kategori } & $\begin{array}{c}\text { Sangat } \\
\text { Bagus }\end{array}$ & Bagus & Bagus \\
\hline
\end{tabular}

Berdasarkan tabel diatas hasil perhitungan nilai parameter QoS sebelum melakukan manajamen bandwidth dengan rentang waktu, menunjukkan ratarata nilai throughput adalah $362,56 \mathrm{Kbps}$, sedangkan nilai delay adalah 29,84 ms dengan kategori latensi "Sangat Bagus", sedangkan nilai jitter adalah 55,53 ms dengan kategori degradasi "Bagus", sedangkan nilai packet loss adalah 14,29 \% dengan kategori degredasi "Bagus".

Dapat disimpulkan dari Tabel 6 dan Tabel 7, bahwa nilai rata-rata throughput mengalami penurunan, hal ini disebabkan pembagian share bandwidth yang diberikan kepada client secara merata. Nilai delay mengalami peningkatan, yaitu penurunan nilai dari sebelum ke sesudah dengan kategori latensi "Sangat Bagus". Sedangkan untuk nilai jitter dan packet loss mengalami peningkatan dari kategori latensi "Sedang" menjadi kategori latensi "Bagus".

Adapun hasil rata-rata pengujian di masingmasing parameter QoS dari sebelum manajemen bandwidth dan setelah manajemen bandwidth dengan metode PCQ sebagaimana tampil pada Gambar 2. 


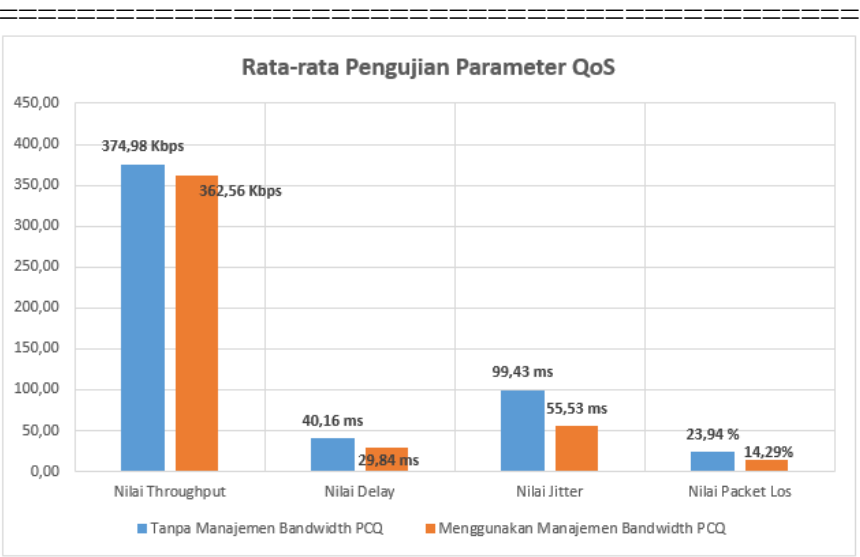

Gambar 2. Nilai rata-rata pengujian parameter QoS

Berdasarkan Gambar 5.2 nilai rata-rata pengujian parameter QoS pada parameter throughput dengan manajemen bandwidth metode PCQ maupun yang tidak menggunakan metode PCQ. Manajemen bandwidth tanpa metode PCQ diperoleh throughput sebesar 374,98 Kbps, sedangkan menggunakan manajemen bandwidth dengan PCQ diperoleh throughput sebesar 362,56 Kbps. Dari kedua data tersebut dapat disimpulkan, bahwa setelah dilakukan manajemen bandwidth metode PCQ mengalami penurunan throughput sebesar 12,42 Kbps. Hal ini menunjukkan bahwa kemampuan suatu jaringan dalam melakukan pengiriman data mengalami penurunan, yang disebabkan pembatasan bandwidth yang diberikan merata ke multi client.

Hasil nilai delay rata-rata sebelum dilakukan manajemen bandwidth metode PCQ adalah 40,16 ms dengan kategori latensi "Sangat Bagus", sedangkan untuk sesudah nilainya adalah 29,84 ms dengan kategori latensi "Sangat Bagus". Setelah dilakukan manajemen bandwidth dengan metode PCQ, nilai delay mengalami penurunan. Hal ini menunjukkan bahwa bahwa pengaruh manajemen bandwidth terhadap waktu yang dibutuhkan untuk menempuh data sampai ke tujuan.

Hasil nilai rata-rata jitter sebelum dilakukan manajemen bandwidth metode PCQ adalah 99,43 ms dengan kategori degredasi "Sedang", sedangkan untuk sesudah nilainya adalah $55,53 \mathrm{~ms}$ dengan kategori degredasi "Bagus". Hal ini dapat disimpulkan bahwa nilai jitter yang diakibatkan oleh variasi-variasi dalam panjang antrian, dalam waktu pengolahan data, dan juga dalam waktu penghimpunan ulang paket-paket data dalam perjalanan semakin membaik setelah dilakukan manajemen bandwidth metode PCQ.

Hasil nilai rata-rata packet loss sebelum dilakukan manajemen bandwidth metode PCQ adalah $23,94 \%$ dengan kategori degredasi "Sedang", sedangkan untuk sesudah nilainya adalah 14,29\% dengan kategori degredasi "Bagus". Dapat disimpulkan dengan menurunya packet loss, menunjukkan bahwa jumlah paket data yang dikirim tidak banyak yang hilang. Hal ini diakibatkan penurunan signal pada WLAN (hotspot), terjadi tabrakan data, melebihi batas saturasi jaringan, dan kesalahan pada perangkat jaringan

\section{KESIMPULAN}

Kesimpulan penelitian ini adalah parameter download, upload, throughput, delay, jitter, dan packet loss yang menunjukkan rata-rata nilai sebelum dilakukan manajemen bandwidth metode PCQ pada throughput adalah $374,98 \mathrm{Kbps}$, nilai delay adalah 40,16 ms dengan kategori latensi "Sangat Bagus", nilai jitter adalah 99,43 ms dengan kategori degradasi "Sedang", nilai packet loss adalah 23,94 \% dengan kategori degredasi "Sedang". Sedangkan setelah melakukan manajemen bandwidth nilai throughput adalah 362,56 Kbps, nilai delay adalah 29,84 ms dengan kategori latensi "Sangat Bagus", nilai jitter adalah 55,53 ms dengan kategori degradasi "Bagus", nilai packet loss adalah 14,29 \% dengan kategori degredasi "Bagus". Manajemen bandwidth metode PCQ bekerja dengan sebuah algoritma yang akan membagi bandwidth secara merata ke sejumlah client yang aktif. PCQ ideal diterapkan apabila dalam pengaturan bandwidth kesulitan dalam penentuan bandwidth per client.

\section{DAFTAR PUSTAKA}

[1] R. Towidjojo, "Mikrotik Kung Fu: Kitab 3," 3 ed., Jakarta: Jasakom, 2016.

[2] R. Towidjojo, "Mikrotik Kung Fu : Kitab 2,” 2 ed., Jakarta: Jasakom, 2013.

[3] E. Febriyanti, S. Raharjo, dan M. Sholeh, "PERBANDINGAN MANAJEMEN BANDWIDTH MENGGUNAKAN METODE FIFO (FIRST-IN FIRST-OUT) DAN PCQ (PER CONNECTION QUEUE) PADA ROUTER MIKROTIK," JARKOM, vol. 5, no. 2, hal. 89-98, 2017.

[4] T. Pratama, M. A. Irwansyah, dan Yulianti, "Perbandingan Metode PCQ, SFQ, RED Dan FIFO Pada Mikrotik Sebagai Upaya Optimalisasi Layanan Jaringan Pada Fakultas Teknik Universitas Tanjungpura," J. Tek. Inform. Univ. Tanjungpura, vol. 3, no. 3, hal. 298-303, Okt 2015.

[5] A. I. Wijaya dan L. B. Handoko, "Manajemen Bandwidth Dengan Metode Htb ( Hierarchical Token Bucket ) Pada Sekolah Menengah Pertama Negeri 5 Semarang," J. Tek. Inform. Udinus, vol. 1, no. 1, hal. 5-7, 2014.

[6] M. F. Asnawi, "APLIKASI KONFIGURASI 


MIKROTIK SEBAGAI MANAJEMEN

BANDWIDTH DAN INTERNET GATEWAY

BERBASIS WEB," J. Penelit. dan Pengabdi. Kpd. Masy. UNSIQ, vol. 5, no. 1, hal. 42-48, Jan 2018.

[7] Mirsantoso, T. U. Kalsum, dan R. Supardi, "Implementasi Dan Analisa Per Connection Queue ( Pcq ) Sebagai," J. Media Infotama, vol. 11, no. 2, hal. 139-148, 2015.

[8] Aji Supriyanto, "Analisis Kelemahan Keamanan pada Jaringan Wireless," J. Teknol. Infromasi Din., vol. 11, no. 1, hal. 38-46, 2006.

[9] F. I. Aziz, B. A. P, dan R. Ritzkal, "SISTEM MONITORING JARINGAN DAN OPTIMALISASI MANAJEMEN BANDWIDTH DENGAN ALGORITMA HTB (HIERARCHICAL TOKEN BUCKET) PADA ZABBIX DENGAN NOTIFIKASI SMS GATEWAY DAN EMAIL (STUDI KASUS DINAS KOMUNIKASI DAN INFORMATIKA KAB. BOGOR)," Pros. Semin. Nas. ENERGI Teknol., hal. 231-245, Apr 2018.

[10] TIPHON, Telecommunications and Internet Protocol Harmonization Over Network (TIPHON) General aspects of Quality of Service (QoS). France: ETSI, 1999.

[11] N. F. Puspitasari dan A. Dahlan, "Analisa Trafik dan Quality of Service (QoS) untuk Optimalisasi Manajemen Bandwidth (Studi Kasus: Universitas Amikom Yogyakarta)," Dasi, vol. 18, no. 3, hal. 63$70,2017$. 